\title{
Dialogical Dynamics and Subversions of Political and Ideological Boundaries in Chinua Achebe's Anthills of the Savannah
}

\author{
Motasim Almwajeh ${ }^{1}$ \\ ${ }^{1}$ Department of English, Hashemite University, Zarqa, Jordan \\ Correspondence: Motasim Almwajeh, Assistant Professor, Department of English, Hashemite University, Zarqa \\ 13115, Jordan. E-mail: motasimrawashdeh@hu.edu.jo
}

\author{
Received: February 21, 2019 Accepted: March 24, 2019 Online Published: April 6, 2019 \\ doi:10.5539/ijel.v9n3p126 URL: https://doi.org/10.5539/ijel.v9n3p126
}

\begin{abstract}
This article examines the subtle allegorical political nuances and implications in Chinua Achebe's Anthills of the Savannah (1987). The novel foregrounds and grapples with the problematics of voice, representation, and history where the more inclusive voice appears to be, the more suppressive and exclusive of other voices it is. Hence, the text enacts a journey toward a realm that rises above gender and class-based rigidities, fusing facets of Nigerian sociopolitical and environmental crises (in the past and present). The novel takes on multiple narratives that engender continuation and sharing vis-à-vis historical realities of political cleansing and ideologies and systems of exclusion. Counteracting condescendingly patronizing doctrines and reductive dichotomies, dialogism and ecofeminism pay equal attention to all parties and reject polarizations and divisions. A combination of these approaches precludes tantalization, and it also humanizes ecofeminism and gives it a wider scope. In principle, combined, these approaches guard against any rejectionist or exclusionary superstructures they seek to deconstruct. Ecofeminism, much like Bakhtinian dialogism in its quest for justice, hinges environmental degradation to gender-based, class-based, racist, and imperial variables, and it disrupts these ideologies and systems of oppression in order to assuage human and nonhuman conditions.
\end{abstract}

Keywords: Achebe, Anthills of the Savannah, dialogisms, ecofeminism, history, political allegory, representation, voice

\section{Introduction}

Readers and critics of Chinua Achebe's Anthills of the Savannah (1987) often find a multi-voiced and multidimensional dissenting text resonating with political and ecofeminist undercurrents and ramifications. Fraught with historical and political impulses and urges and dialogical and ecofeminist alternatives and sensibilities, Anthills of the Savannah revolves around three main characters who negotiate and invalidate a range of dysfunctional hegemonic systems of thought (such as patriarchy and sexism) and search for voice and representation. It also sheds much light on the legacy of colonialism and the subsequent injustices and hierarchies retained in it. Most importantly, no study combining and applying Bakhtinian dialogisms and ecofeminism to Anthills of the Savannah has been found, so the paper offers a fresh and original reading of the novel from these perspectives.

Metz (1991) explains that "Nigerian history is fragmented in the sense that it evolved from a variety of traditions, but many of the most outstanding features of modern society reflect the strong influence of the three regionally dominant ethnic groups - the Hausa in the north, the Yoruba in the west, and the Igbos in the east" (p. 3). One will probably come across these valid generalizations in almost every book on Nigerian history. Such overgeneralizations entail the dominance of these three groups or voices over hundreds of smaller groups that are either lulled into the realm of the nonexistent or vilified Other. Interestingly, Achebe never uses the name Nigeria in the novel, but no one can escape its being a vibrant political parable for which one can easily find general counterparts in documented Nigerian history. This latent political allusion or critique marks an old literary practice known since the time of Geoffrey Chaucer, and it is still commonly practiced in third-world autocracies, where authors employ fables and myths as elusive artifices or ruses to tackle real-life situations in the hope of avoiding accountability for their non-conforming political principles. 


\subsection{Introducing the Problem}

As previously stated, the researcher has not come by a single study that addresses the dialogical and ecofeminist nuances in the novel in connection to real-life situations. Most studies that the researcher has located focus on the strong female figures presented in the novel and the fact that Achebe is deviating from his former reproachful portrayals of female figures. This time, he offers dynamic female figures who strive to subvert the oppressive status quo and construct a solid ground for women. Evidently, this paper considers a relatively old novel from a completely new angle, one that has not been tacked yet.

\subsection{Importance of the Problem}

This study endeavors to weave an intricate theoretical basis on which Achebe's Anthills of the Savannah can be freshly explored in order to contribute a new path of gender-based and political dissent, one that gives women and marginalized groups agency and voice. To this end, the novel traces the struggle of Beatrice, an epitome of an educated African woman, against the marginalization of women, so she, as a forceful leading figure, takes an active part in political and social affairs and reformations. Beatrice links the impoverished position of women to the overall despotic situation in the nation, and condemns people's passivity vis-à-vis defying those at the top of the ladder who exploit the country and its people for their own selfish gains. Plainly, when unquestioned, the president squanders the nation's resources on extravagancies and personal aggrandizements. The funds which would have been used to develop the country are dissipated on the so-called Presidential Palace, which has become the Seat of Corruption. Again, Major Sam's involvement in public executions and his attempt to rape Beatrice at the party attest to the depth of moral and political corruption that has eroded the continent.

\subsection{Strategies of Resistance}

For instance, Ikem Osodi, the second main character, retells the story of the tortoise, handed down to him by the wise elderly leader of the delegation from Abazon. Both characters recount the folk tale in order to subtly galvanize resistance to the oppressive "head of state". The elderly leader's narration of the dissenting tale renders him incarcerated "in solitary confinement at the Bassa Maximum Security Prison" (p. 141). The underlying premise of the story foments hope, struggle, and resistance even under the worst of conditions because even if one fails, the impact of one's action can still be felt, and this abortive attempt may still instigate and mobilize others. Caught by the leopard after being chased for a long time, the tortoise is granted a chance to do one last thing before it is killed. The tortoise "is scratching with hands and feet and throwing sand furiously in all directions" (p. 117). Curious, the leopard asks the tortoise why he is doing this, and the tortoise replies, "Because even after I am dead, I would want anyone passing by this spot to say, yes, a fellow and his match struggled here" (p. 117, Emphasis in Original). Although the tortoise dies, its traces are kept for future generations. The old man from Abazon delivers a very important speech on the importance of storytelling because, in the end, the fighter passes away - the storyteller passes away, but the story remains as long as it finds somebody to write it down, even if it is a story of defeat. In the words of the elder, "we are . . struggling. Perhaps to no purpose except that those who come after us will be able to say: True, our fathers were defeated but they tried" (p. 128).

\section{Relevant Scholarship and Literature Review}

Most scholars interpret Achebe's Anthills of the Savannah as either introducing a revolutionary potent female figure in charge of her own future and thus capable of empowering, inspiring, and criticizing others or as an extended political allegory. Hence, it offers a scathing critique of the many forms of injustice in postcolonial Nigeria and interweaves a canvas of the intricate political and gender-based paradigms of oppression. Set in a fictional postcolonial Kangan (suggestive of Nigeria), the novel unveils the underlying insecurities and incongruities of patriarchal and elitist political institutions that seize and manipulate power and eliminate the voices of the masses. The metamorphosis of the major characters is seen through the transformation of their voices and the maturation of their political coherent agendas. Attesting to the core of Nigerian dilemmas as mainly stemming from the exclusion of the masses, Achebe (1983), who inscribes a special niche for himself, declares that "the masses are the real victims of our callous system, the wretched of the earth. They are largely silent and invisible" (p. 24). He adds, "They drink bad water and suffer from all kinds of preventable diseases. The politician may pay them a siren-visit once in four years and promise to give them this, that and the other. He never says that what he gives them is theirs in the first place" (p. 24). Remarkably, Achebe borrows Fanon's most famous phrase, "the wretched of the earth", to describe the dispossessed masses whose counteracting voices are brutally silenced and their freedom of expression is suffocated.

Nutsukpo (2012) focuses on the feminist undercurrents of the novel and illustrates that Beatrice is a "radical feminist" figure "who is portrayed as an intellectual who is incredibly intelligent... Beatrice's feminist perception of independence and selfhood embodies her lifestyle as an individual and a single woman" (pp. 160- 
161). Much like Nutsukpo, Acholonu (1996) traces the growth of female characters throughout Achebe's body of work and concludes that Beatrice is the most powerful female character evolving in his oeuvre. Nutsukpo asserts that Beatrice signifies Achebe's development of a female figure deviating from the norms or confinements of patriarchy, one who "could wield the power of sustaining peace, commonsense, and humanism in a world threatened by the tyrannical rule of a despot and the untempered fanaticism of egocentric, revolutionary ideas" (p. 320). She adds that, in Anthills of the Savannah, Achebe envisions women as leaders of constructive change when they break free of the shackles of patriarchy and forge a special niche for themselves. Most critics acknowledge Achebe's inclusion of traditional patriarchal societies in which women struggle against a number of obstacles. They concur that Anthills of the Savannah marks Achebe's first departure from his previous strategy of providing dysfunctional female figures. Instead, readers find in Beatrice an empowered functional dynamic female who controls much of the narrative and directs and shapes the course of events. According to Agbasiere (2004), "In Anthills of the Savannah, the woman is dignified and free to live her life the way she wants. Traditional constraints are out of the way and the more educated she is, the more her prestige rises, and the more she is a good candidate for the governance of the community" (p. 364).

Clearly enough, Achebe diverges from his former description of women as only holding limited domestic roles. The barriers and restrictions put on women have blurred and even transcended. According to Mikell (1995), Achebe is

no longer at ease in his creation of women with limited roles. The walls of the harem confining women have fallen apart and Achebe can no longer hold on to the peripheral role that is contrary to the reality of the African woman in changing society. Women are therefore seen participating dynamically in and activating social change (p. 405).

Overall, prior studies suggest that most critics tackle gender-based and political questions and allegories pervasive in the novel, and they tend to investigate the implications of resistance and people's refutation of tyranny and being excluded and deprived of their rights and of any sense of integration or participation.

\subsection{Theoretical Foundation}

Using an interdisciplinary approach of Bakhtinian dialogisms and referring to ecofeminist assertions, this article offers an explication of Achebe's dramatization of the failure of Bakhtinian dialogisms between those in power and those without power, and this failure marks the decline of successful dialogue among the components of Nigerian society. The word interdisciplinary refers to merging these two theoretical disciplines into one framework, one that consciously applies methodology and terminology from a number of critical domains to investigate a specific issue or theme, or even work. Before delving further into an inquiry of the dialogical and ecofeminist insinuations in the novel, the researcher elaborates on the foundations of these theoretical domains in order to apply them to the text.

\subsection{Why an Interdisciplinary Approach?}

The researcher opts for an interdisciplinary investigation because no single theory can generate a holistic approach on its own. For example, Murphy (1995), conscious of the limitation of each critical domain, proposes a thorough analysis of Bakhtinian dialogism and ecofeminism and contributes an exceptional synthesis that pairs these intersective and overlapping critical spheres. Hence, one needs a mixture of these approaches (i.e., feminism is already a blended form retaining ecology and feminism) that complement each other and thus redeem the shortcomings of each. Together, these theories constitute an overreaching inquiry lacking in some other critical fields that are either reactionary or bound to simulate and replicate the same reductive systems they embark to thwart. In fact, these approaches comprise a comprehensive approach to life, counteracting patriarchal supremacist superstructures of the reduction and erasure of the Other. Commenting on the scope of these approaches, Murphy (1995) states, "In marked contrast to the critical maladies of enervated humanism, solipsistic skepticism, and paralytic undecidability, a triad of (re)perceptions has appeared, which, if integrated, can lead toward an affirmative praxis: the Bakhtinian dialogical method, ecology, and feminism" (p. 3).

The Bakhtinian dialogisms carve an inalienable space for agency and ground the individual as a responsible and ethical agent only if one participates with and respects human and non-human others. Bakhtin (1993) holds that

The world in which an act or deed actually proceeds, in which it is actually accomplished, is a unitary and unique world that is experienced concretely: it is a world that is seen, heard, touched, and thought, a world permeated in its entirety with the emotional-volitional tones of the affirmed validity of values. The unitary uniqueness of this world... is guaranteed for actuality by the acknowledgment of my unique participation in that world, by my non-alibi in it. This acknowledged participation of mine produces a concrete ought - the 
ought to realize the whole uniqueness of being, in relation to every constituent moment of this being; and that means that my participation transforms every manifestation of myself (feeling, desire, mood, thought) into my own actively answerable deed (pp. 56-57).

Here, Bakhtin synthesizes a complex holistic form of realism that overcomes the inherent underpinnings of Western metaphysics of division and polarization and argues for a "unitary" doctrine that gives proportionate merit to all parties of the dialogical process.

\subsection{Participation and Love in the Place of Division and Hatred}

In Bakhtinian philosophy, priority goes to participation and integration in the place of exclusion. While he stresses the necessity of participation, most other philosophers opt for ascendency, detachment, and division. For him, the self is a participatory entity that encompasses all the tenets and faculties of the participative agent; the "manifestation of myself" includes "feeling, desire, mood and thought" (Bakhtin, 1993, p. 57). Further, participating entails sharing the world of the others and transcending self-other superimposed limitations. Hence, all attempts to place the self aside or above, as superior to others, verge on fallacies that reject this "unitary" and complementary side of existence. Grippingly, Bakhtin develops a special notion of love as fundamental to aesthetic considerations. It is not to fill a dearth in the self; rather, love requires attention to and recognition of the unitary nature of human and nonhuman existence. It is an all-embracing, dialogic, or even multi-logic tendency toward life and flexibility, a propensity that rules out self-shrinking into the monologic. However, Bakhtin still admits to the pivotal status of human beings in respect of their linguistic ability that endows them with faculties other creatures do not enjoy (Bakhtin, 1993, pp. 56-60).

Bakhtin's sense of love and sharing is, in effect, adopted by ecofeminists due to the domains it opens if applied to literary criticism and even to life in general (Donovan, 1996, pp. 84-86). Bakhtin argues that "Only love is capable of holding and making fast all this multiformity and diversity, without losing or dissipating it, without leaving behind a mere skeleton of basic lines and sense-moments" (1996, p. 64). Bakhtin's love breeds reverence for others and eschews any abstractions that strip the entity abstracted of any sense of dignity and legitimize cruelty against it. Loving the other fosters a dialogical affinity with human and non-human entities and blurs self-other boundaries and limitations, condoning the so-called "pure self" as a fallacy. Just like stereotyping, abstraction subordinates and erodes the other to the realm of the worthless or the dangerous that should be crushed and subjugated.

\subsection{Fundamental Ecofeminist Postulations and Contestations}

Adams (1993) impugns another thorny hierarchical technique in addition to abstraction, and she calls it "transference" or "metaphorizing" of the Other to the realm of another subordinate Other on the basis of associating women with nature. This correlation exacerbates the already subservient position of women in patriarchal cultures. Representing nature as the mother is seemingly employed to elevate the status of nature, but, in the words of Roach (1996), such associations "will not achieve the desired aim of making our behaviors more environmentally sound, but will instead help to maintain the mutually supportive, exploitive stances we take toward our mother and toward our environment" (p. 53). Plainly, women and nature are confined, and they are expected to accede and give unconditionally, and that is why Roach (1996) stresses that scholars should "see clearly the Earth as Earth and not as the mother or female we have imagined the earth to be" (p. 55). According to Adams (1993), ecofeminists "demonstrated how metaphors of patriarchy simultaneously feminize nature and naturalize women" (p. 1). And these arrangements of relegating one entity into another realm-women to the realm of the natural, the natural itself to the evil-place some ecofeminists in a state of confusion. On the one hand, boundaries between the natural and the human are artificial and even responsible for humans' alienation from nature. However, because of patriarchy, women, much like nature, are stigmatized in the realms of the many "subs" of culture.

\subsection{Colonialism Aggravated an Already Dilapidated Situation}

With the advent of colonialism, the indigenous people (pitted against one another) are divided into hierarchies of exploitations, and they are valued and devalued depending on their face value, not depending on their ethical or cultural merit. Pre-colonial counties were not, by any means, living on a bed of roses, but life was less complicated and more morally controlled and driven in an integrative manner. In traditional societies, people conversed and debated constantly, learning from one another and sharing experiences. However, the political reality in African fiction tackles, directly and indirectly, not only issues pertaining to political cleansing but also the suppression of deviating forces. It is not only a thorny dichotomous hinge with the other (which is always the case) but also negating the Other and desiring to permanently wipe it. Patriarchal forces act violently and thereby 
frustrate any possibility of reconciliation between the center and the margin. In line with Bakhtin, Murphy holds that the very existence of the center rests on the periphery.

\section{Methodology}

The research methodology employed in this paper comprises a concise analysis of Achebe's Anthills of the Savannah in light of the above theoretical foundations. Working within a specific frame of an interdisciplinary utilization of Bakhtinian dialogisms and ecofeminist hypotheses aid the researcher in cementing his stance on applying a combination of the premises of these critical domains in order to reengage literature with real-life situations and better decipher the interlacing dialogical implications entailed in the novel. These approaches help expound Achebe's delineation of the failure of Bakhtinian dialogisms and thus stretching the gap between the centers of power and the powerless subaltern others. Basically, the novel is critically evaluated within the parameters of these theories. In order to substantiate the basic arguments in this paper, the researcher incorporates much textual evidence in order to support the key ideas, answer questions, and make claims. In addition to textual evidence, which is the most commonly used tool, several sources concurring with my corroborations are included so as to validate my hypotheses and foster a wider treatment of the novel's inherent messages.

\section{Analysis}

The narrative commences with Christopher Oriko (Chris) as the first witness of the government's covertly devious machinations and schemes. The first scene at the Presidential Palace exposes the appropriation of actions and the silencing of voices that deviate from the whims of the military dictators. The narrator admits his own complicity in and consent to be degraded to the status of the rat that has to keep running to its hole whenever it hears a sound. Ironically, hunting images pervade the narrative. Dooming the other to the realm of the animal strips human beings of their humanity and justifies violence against them, as cruelty to animals is antecedent to violence against people.

Intrepid enough to suggest that the president should visit the drought-stricken region of Abazon, Chris is portrayed as more diplomatic than the other members of the cabinet because he criticizes himself and moderately tries to reform the status quo. Chris, adamant on reporting and documenting the unofficial truth to the public, decides not to resign his position as a member of the cabinet despite his disapproval of the tyrannical practices of the regime. In so doing, he provides an inside insight into the government's schemes.

Although he is muted, Chris introduces the reader (through recording and writing down) to a "subaltern" history unavailable in official media. Contrite, he affirms the motives behind his service in the cabinet though later he is denied the right to continue in or resign his position: "And, of course, complete honesty demands that I mention one last factor in my continual stay, a fact of which I'm somewhat ashamed, namely that I couldn't be writing this if I didn't hang around to observe it all. And no one else would" (p. 2).

\subsection{Dialogisim in Narrative Voice}

The narrative of the novel is dispersed among three characters and an omniscient narrator who intervenes to supply information of which the other characters fall short. The four narrators alternately take over the narrative thread and provide for discursive diversity and plurality. Compatible with the themes of the novel, the narrative advocates poly-vocality and juxtaposes the manifold voices as partly claimants to the truth. The narrators question their own voices, examine their relationships to their narratives, rationalize their voices, and even minimize the importance of their voices as presenting one side of the truth. More and more, dialectical perspectives, resulting from multi-vocality, substitute monological attitudes and approaches. Much like Chris, Ikem Osodi, a charismatic poet and newspaper columnist who deprecates the so-called impeccable President, becomes a lively voice of dissent and the second witness to the dialogical and discursive nature of the narrative. This dialogically engaging dynamic is manifested in the amalgamation of diverse voices that evolved throughout the novel. Thus, the voice of the first witness is played against that of the second, and the narrative keeps shifting until it encompasses all voices.

In this way, a voice cannot materialize without a listener who should be the target of the speech act or the reciprocal process, so the existence of the narratee becomes as vital as that of the narrator to the perpetuation of the whole process of writing and narration. For example, Beatrice Okoh, the strongest female figure with a remarkable acumen, occupies this slot of the interlocking paradigms of ecofeminism and the Bakhtinian principles of dialogics, and this is why when the two male narrators are silenced, Beatrice carries on their narrative. Warren (1993) defines the dysfunctional as placing tremendous value on control, exaggerated rationality and many other mechanisms that incapacitate the individuals and make them feel helpless (pp. 124- 
128). All the social classes and the two genders are involved in this mutually defining process, and women play an impregnable role in the novel-unlike their traditional roles in Achebe's previous novels. In this novel, Achebe's incorporation of dialogics strikes a note of optimism and a grassroots political advocacy of the necessity of dialogue and cooperation among all the components of society to shield against tyrannical regimes.

\subsection{Myriad Forms of Dissent}

Juxtaposed, Ikem and Chris exchange accusations and pass through a period of separation and tension due to their political contentions and discrepancies. Chris tells Beatrice that Ikem is a romantic, picaresque, revolutionary, and detached artist-poet, much like Stephen Daedalus in James Joyce's A Portrait of the Artist as Young Man. Chris espouses restraint and diplomacy as more moderate opposition stances or tactics than those adopted by Ikem. Yet, Ikem's picaresque characteristics gradually alter after he develops a more enlightened voice and thereby abandons the role of the utopian in favor of the role of the true reformer.

Ikem is the closest to the bottom of the socioeconomic ladder, and he is the first to start reappraising his long unquestioned bond to the public. His girlfriend Elewa belongs to the low-class market women, and his old car does not tell of his notable social stratum. Many people (i.e. the taxi-drivers) misidentify him as an "ordinary" man like themselves. Beatrice, who keeps warning him against barring women from his political agenda and art and against confining them to the traditional roles of the latecomers, helps much in his transformation afterward. The role he gives women is contrary to his convictions of women's emancipation and enfranchisement and his search for a reconnection with the underprivileged and the unrepresented. He later acknowledges his shortsightedness, telling Beatrice: "your charge has forced me to sit down and contemplate the nature of oppression" (p. 88). Elsewhere in the novel, he resolves the mystery behind the failure of his attempt (and of all parallel reformations) at relating to the oppressed: "You reform it around what it is, its core of reality, not around an intellectual abstraction ... Those who would see no blot of villainy in the beloved oppressed nor grant the faintest glimmer of humanity to the hated oppressor are partisans, patriots and party-liners" (pp. 91-92).

Ikem criticizes the false invocation of the public as long as they are absent, and he notices the long practice of appropriating their right to speak for themselves. They have been spoken for by intellectuals and politicians who do not share their prevailing universe of discourse. Hence, the subaltern groups continue to carry out a ghostly presence until they start to substantiate and gain solid ground by the end of the narrative. Earlier in the novel, they are invoked as a ruse or as a commemorative ritual of death, and the moment they are acknowledged, they vanish from the scene. In most of the political speeches, the masses are conjured as a legitimizing force that gives one an undisputed right and privilege.

\subsection{Voice and Agency Given to Women and the Masses}

Ikem's unearthing of the merit of the voice of the people takes place by accident in contrast to other politicians whose appeal to public representation and legitimacy is a politically conscious game. The distancing is taken and planned so that the middle ground is missing, and an almost unbridgeable hiatus opens between the rulers and the ruled. All these strategies fail to anchor a hinge with the public. Ikem attempts to dissociate himself from the diversionary wars. He realizes the peril of reducing the history of the nation to the personal or semi-personal conflicts that alienate the real subjects of history and hinder any struggle for reform in the country. Rajan and Mohanram (1995) discuss the fallacy of identifying the history of a nation with the history of those in power, a general tendency in postcolonial countries. They insightfully point out that "[a]nother recurring theme within the context of postcoloniality is identity politics, which indicates one's use of personal experience as the basis of one's politics" (p. 13). This principal quotation seems to be at the back of Achebe's mind in his awareness of how the history of a whole nation may be reduced to the history of the individual(s) in power. It is not wrong to use one's experience in writing history, but it is too self-conceited to shrink the history of a nation to the history of a few people, mainly those at the top of the sociopolitical ladder. Ikem is fully aware that these diversionary wars are merely political ruses launched to divert public attention from other urgent domestic questions and exigencies - a strategy that diminishes the multitudes of diverse voices of the oppressed poor to one monological voice and gives the public a voyeuristic role. Unfortunately, this monological scenario replaces a participative dialectical approach in which all groups of people and the two genders are fully engaged and represented in real political agendas and reformations.

Beatrice forcefully disputes the denigration of women even within resisting groups, urging Ikem and Chris to sit together and talk, and not only resort to abstraction and one-sided views. She impels them to involve others in their voices and postulations. At one point she says to Chris: "Well, you fellows, all three of you, are incredibly conceited. The story of this country, as far as you are concerned, is the story of the three of you" (p. 60). This 
key insight designates that the history of Kangan (Nigeria) is simply the story of single individuals - their coups, whims, and conflicts - excluding the masses' voice and paradigm.

But, Beatrice, not ethnically identifying with anyone, might be alluding to the story of the three dominant groups in Nigeria without regard for the many remaining minor ethnic groups. Chris admits to this fact: "We are all connected. You cannot tell the story of any of us without implicating the others ... The story of this country, as far as you are concerned, is the story of the three of you... We tend sometimes to forget that our story is only one of twenty million stories - one tiny synoptic account. But that's the only one I know" (p. 66). He does confess to his limitability and ignorance of what he calls the other "twenty-two million" stories, giving a disproportionate ratio of 3 to 22 millions. This may also be a reference to the level of representation of those at the bottom by those at the top. This strategy expounds Ikem's anger at the broadcasting of his alleged coup and regicide plot as main actions, while the news of the arrest of the six leaders from Abazon and their disaster-stricken region is given little or no regard. This is just another diversionary tactic from the real urgent political and economic problems of the drought-stricken region of Abazon.

The true version of the story is that, because of the untold hardships afflicting the Abazon region, the people of Abazon "send a deputation of elders to the government who hold the yam today, and hold the knife, to seek help of them" (p. 33). Hence, a group of elderly people try to convene with the president alleging obedience to the President and proposing dialogue instead of monologism and "alienation". However, the President has inflicted his own godlike curse on them since they have said "no" when they should have said "yes". They submit, against their nature and self-dignity, seeking the federal government's help to relieve their arid region, but the government's mill transforms them into conspirators, and so they are persecuted and arrested. More tragically, they are even deprived of airing their predicament before the President. Nobody hears their voice except Ikem and some people at the restaurant. These listeners applaud the old man's sense of humor, candor, and skilled use of political allegories to implicitly fulminate against the president. However, no relief action is taken to alleviate their suffering.

Through "Hymn to the Sun", Ikem brings to the fore the roots of myths and storytelling in Abazon. As an allegory in which the sun is a symbol of His Excellency, the myth captures the whole dynamic tension of power relations and maldistribution, and functions as a subterfuge to offer a scathing critique of the president's reluctance to perform the duties entrusted to him as the head of state, because the people of Abazon do not endorse or give consent to his craving to be president for life. The anthills are symbols of regeneration and renewal, "like the anthills surviving to tell the new grass of the savannah about last year's brush fires" (p. 28). The novel also reveals polemical elements about the past which, albeit its brutality, was more unencumbered with a bigger degree of mobility to cross regions, a movability reminiscent of a nomadic lifestyle. Now, movability is restricted: "today no one can rise and march south" (p. 30). The old man gives voice to the anguish of Abazon's indigenes in Bassa (the capital): "It is the story that owns us and directs us ... it is the mark on the face that sets one people apart from their neighbours" (p. 124).

Ikem's, Beatrice's, and then Chris's grasp of this fact opens new horizons of communication that would dissolve class-based and ethnic boundaries: This finding is not radical since the new emergent voices are not following Marxist's dialectics of the inevitable cross-class conflicts. The final naming ritual exemplifies the expansion of voice to include and present, rather than represent, almost all sects and groups of society-intellectuals, servants, drivers, market women, Christians, Muslims, civilians, military men, old and new generations.

\subsection{Gender Balance and Female Solidarity}

In chapter 6, the floor is given to Beatrice, whose cogent rhetoric or discourse strikes a balance with the hitherto predominantly masculine voice, so her voice projects a counter-discursive posture against male-dominated paradigms of thinking. She and the omniscient narrator manipulate the rest of the narrative and shape and filter readers' perception of most of the remaining stories and cultural myths, mostly resonating with themes of struggle against complacency and conformity to the tyrannical status quo. As the single most inclusive and most neutral among all the voices in the novel, Beatrice's voice foregrounds all groups, and most essentially forges a fair status for women. Hence, she plays a spinal role in the novel, one that empowers her to channel her reservation at Ikem's belated and laggard inclusion of the voice and view of female figures and experience: "It is not enough that women should be the court of last resort because the last resort is a damn sight too far and too late! That was about the only serious reservation I had about Ikem's political position" (p. 93). Beatrice embarks on writing her own version of the story: "For weeks and months after I had definitely taken on the challenge of bringing together as many broken pieces of their tragic history as I could lay my hands on, I still could not find a way to begin" (p. 82). She adds, "Anything I tried to put down sounded wrong - too abrupt, too indelicate, or too 
obvious - to my middle ear" (p. 82). This is also true of the story of Nigeria. Her writing process is identified by her as an act of trespassing: "treading where angels would fear to tread", or rather "pulling up the spears thrust into the ground by the men in the hour of their defeat and left there in the circle of their last dance together" ( $p$. $83)$.

That Beatrice's name is reduced to the initials BB offers subaltern groups a prospect of being integrated insomuch as it stirs hope that the suppressed story of Nigeria and the truth of the coup attempt will be revealed. She becomes our main source and parameter after the floor is purged of masculine voices. She explains her having a traditional name she dislikes and suppresses: "Nwanyibuife - a female is also something" (p. 79). It is an old-new story of a female made to feel guilty because of something beyond her. After all, as we don't choose our names, we also have nothing to do with our sex distributions or orientations.

Toward the end, the narrative space shifts from the three male characters dominating the scene to other evolving voices and groups. This transition is made possible after the assassination of Ikem, Chris, and Sam where a growing sense of sedulous attention and solidarity commences among Beatrice, Elewa, and Elewa's baby. According to Stratton (1994), "Seizing the traditional male role of naming the child, Beatrice gives the baby girl a boy's name, Amaechina, 'May-the-path-never-close"” (p. 166). Elewa's fatherless baby is fathered by almost all the other survivors, and when Elewa's old uncle asks about who names the baby, the direct answer is "all of us". The naming ritual, enacting pluralistic multi-vocality, disturbs gender divisions by realizing the right of the female to masculine names and hence to a central role in the modern scene.

More importantly, these characters have, for the first time, started to take part in the narrative as the real representatives of the Kangan community. "[A]nd in the background, narrator's voice coming through and declaring: It is now up to you women to tell us what has to be done. And Agatha is surely one of you" (p. 169). Agatha's voice is integrated and she is set free when Beatrice overcomes the distance separating them. Besides, Beatrice's house becomes a hub for diverse social groups. Agatha's aloofness, sometimes narrow-mindedness, even revolt against Beatrice, all disappear as she starts to sympathize and communicate with other members of society the moment Beatrice touches her sympathetically and caringly. This turn exposes the fragility of these superimposed barriers and limits among the members of society. These borders can be surmounted through the acts of love and dialogue, respecting people's differences and current situations, not as stigmas, but rather as extrinsic accidents of history.

Chris's voice solidifies and gains firmer grounds vis-à-vis the silencing and dictatorial President. His journey to the North and out of Bassa has aligned him with such dissenting voices as Ikem's, Beatrice's, and the masses' voices. The low-class people come to his rescue, and he is forced to spend some time with the true Nigerians and live under their same miserable conditions. This experience shocks him off the cocktail parties' hollowness and remoteness from the true spirit of the Nigerian people. He is forced to play the role of the small man, and he realized that even the small man's world is rich and worthy of respect. Unfortunately, his pilgrimage to Ikem's Abazon is never complete although it yields a humanizing expansion of voice. Chris is enabled, for the first time, to see the taxi-drivers, the peasants, and other low-class women; his voice metamorphosizes from a "disembodied voice" to a "flesh and blood" one. His final education materializes when he opposes the policeman to save a girl from the north, who has become a member of the new emergent vices or consciousnesses as a fruit of his death or martyrdom. Chris now becomes aware of the anthills of savannah.

\section{Discussion}

In view of the above guiding theoretical foundations and the ensuing analyses, Achebe's Anthills of the Savannah raises complex questions about the detrimental rendering of the Other as always evil, an arrangement that can be quickly reversed. The politics of Nigeria (and Africa) in the real world enact a null relationship or a zero-sum game in which the existence of one party entails the elimination of the other: The center is completely intolerant and even contemptuous of the periphery. The two parties perceive one another as immanent sources of danger. The narrative propounds a historical elucidation of Nigeria's political milieu and of how quickly successive Nigerian political leaders slide into despotism abetted by the conscious and unconscious complicity of the Nigerian people. As seen in the narrative, the ruling élite is repressive of the voices of the masses placing itself at the heart of public attention and rarely questioning its own claims to authority as representing the unrepresented "subaltern" classes, to borrow Gramsci's term. The novel attests to the failure of Bakhtinian dialogisms in the Nigerian (and even overall African) context, but it still gives a window of hope for future generations. Just like the parable of the tortoise and the leopard implies, one should try even if he or she already knows that one will probably fail, as this failure may still encourage others to keep trying. We should keep in 
mind that the novel concludes with a note of optimism where female characters take over the narrative, and they can guide everyone in the right direction.

\section{Conclusion}

Anthills of the Savannah raises questions and concerns similar to the ones addressed by Bakhtinian dialogisms and the domain of ecofeminism, as they aim at correcting the situation and restore the sublimity and rights of the culturally and unjustifiably unprivileged part of the equation. Even without ecological hazards, colonial heritage, or racism, one should develop dialogical ethics, not as an outsider to the system, but out of the realization that one is part of the intricate web that includes human and non-human entities. One should always review one's look at the world and the relationships one has with others and nature. The new ethics need to stress sharability and collectivity against patriarchal dyads that doom any workable system of ethics a priori since the prevailing practice would not be really ethical, but hierarchical. Ecofeminism along with Bakhtinian dialogics brings ethics back to the real-life realm away from abstractions and one-sidedness. Diversity propagates and sustains existence, but, in fact, difference is denaturalized, politicized, and hierarchized.

The roots of dividing people into high and low according to gender, race, or any other considerations seem to be deeply economically decided. This is, of course, not a new discovery, but it allows us to re-write history from the point of view of the subaltern and the perspective of those who are never given voice. History should no longer be written from the point of view of the subject: Writing it from the standpoint of the suppressed other corrects the image and sheds much like on the truth. The master narrative manipulates and appropriates voice as it expropriates life and freedom. For example, if the colonial master narrative is written ecologically, it will reveal important facts.

\section{References}

Achebe, C. (1983). The trouble with Nigeria. London: Heinemann.

Achebe, C. (1987). Anthills of the Savannah. New York: Anchor.

Acholonu, R. (1996). Outsiders or Insiders: Women in Anthills of the Savannah. In I. Edith (Ed.), Eagle on Iroko: Selected papers from the Chinua Achebe international symposium (pp. 311-321). Abadan: Heinemann Educational Books.

Adams, C. J. (1993). Ecofeminism and the sacred: Women's writing as transgression. New York: Continuum.

Agbasiere, J. (2004). Feminist Assertion in Achebe's Novels: A Study of Things Fall Apart and Anthills of the Savannah. In E. Ernest (Ed.), Omenka the Master Artist: Critical Perspectives on Achebe's Fiction (pp. 359-365). Trenton, NJ: Africa World Press.

Bakhtin, M. M (1981) Discourse in the novel. In H. Michael (Ed.) \& Caryl Emerson (Trans.), The Dialogic Imagination: Four Essays (pp. 259-422). Retrieved from http://hdl.handle.net/2027/heb.09354

Bakhtin, M. M. (1986). The problem of speech genres. In C. Emerson \& M. Holquist (Eds.), Speech Genres and Other Late Essays (pp. 60-102). Austin: University of Texas Press.

Bakhtin, M. M. (1993). Towards a Philosophy of the Act. Retrieved from https://www.musework.nl/image/2015/6/11/bakhtin_mikhail_toward_a_philosophy_of_the_act.pdf

Donovan, J. (1996). Ecofeminist literary criticism: Reading the orange. Hypatia, 11(2), 161-184. https://doi.org/10.1111/j.1527-2001.1996.tb00669.x

Metz, C. (1991). Nigeria: A Country Study. Washington: Library of Congress.

Mikell, G. (1995). African feminism: Toward a new Politics of representation. Journal Feminist Studies, 21(20) 405-424. https://doi.org/10.2307/3178274

Murphy, P. (1995). Literature, narrative, and other: Ecofeminist critiques. New York: State University of New York Press.

Nutsukpo, F. (2012). Feminist stance and language: A focus on Beatrice in Chinua Achebe's Anthills of the Savannah. In C. Helen (Ed.), Achebe's women: Imagism and power (pp. 159-168). Trenton, NJ: Africa World Press.

Rajan \& Mohanram. (1995). Postcolonial discourse and changing cultural contexts. London: Greenwood Press.

Roach, C. (1991). Loving your mother: On the mother-nature relation. Hypatia, 6, 46-59. https://doi.org/10.1111/j.1527-2001.1991.tb00208.x 
Stratton, F. (1994). Contemporary African literature and politics of gender. London: New York: Routledge. https://doi.org/10.4324/9780203202975

Warren, K. J. (1993). A feminist philosophical perspective on ecofeminist spiritualities. In C. J. Adams (Ed.), Ecofeminism and the sacred. New York: Continuum.

White, H. (1978). The historical text as a literary Artifact. Clio, 3, 277-303.

\section{Copyrights}

Copyright for this article is retained by the author, with first publication rights granted to the journal.

This is an open-access article distributed under the terms and conditions of the Creative Commons Attribution license (http://creativecommons.org/licenses/by/4.0/). 